\title{
The Direction of War: Contemporary Strategy In Historical Perspective. By Hew Strachan. New York, N.Y: Cambridge University Press, 2013.
}

Mark Roberts

Follow this and additional works at: https://digitalcommons.usf.edu/jss pp. 98-99

\section{Recommended Citation}

Roberts, Mark. "The Direction of War: Contemporary Strategy In Historical Perspective. By Hew Strachan. New York, N.Y: Cambridge University Press, 2013.." Journal of Strategic Security 7, no. 3 (2014) : 98-99.

DOI: http://dx.doi.org/10.5038/1944-0472.7.3.7

Available at: https://digitalcommons.usf.edu/jss/vol7/iss3/8

This Book Review is brought to you for free and open access by the Open Access Journals at Digital Commons @ University of South Florida. It has been accepted for inclusion in Journal of Strategic Security by an authorized editor of Digital Commons @ University of South Florida. For more information, please contact digitalcommons@usf.edu. 


\section{The Direction of War: Contemporary Strategy In Historical Perspective. By Hew Strachan. New York, N.Y: Cambridge University Press, 2013.}




\section{The Direction of War: Contemporary Strategy In Historical Perspective. By Hew Strachan. New York, N.Y: Cambridge University Press, 2013. ISBN 978-0-691-13124-5. Sources cited. Index. Pp. xiv, 322. $\$ 76.50$.}

Sir Hew Strachan (O.B.E.) is a War History Professor at Britain's Oxford University and serves as a consultant for the British Defence Ministry. He formerly lectured at the British Royal Military Academy at Sandhurst.

Using a rich backdrop of military history case studies to make his case, Strachan contends that the wars since 9/11 in Iraq and Afghanistan have led to widespread frustration and a sense of failure. Blame for these failures has been attributed to poor strategy, a lack of consistent direction, ineffective communication, and poor governmental coordination. Strachan posits that these failures resulted from a fundamental misreading and misapplication of strategy itself. He argues that the wars since 2001 have not in reality been as "new" as has been stated, and that the U.S. and Britain need to adopt a more historical approach to contemporary strategy in order to identify what is really changing in how the West wages war. If war is to fulfil the policy aims, the U.S. and the U.K. need first to understand war. Pulling no punches, Strachan criticizes both the Bush (\# 43) and Obama administrations for confusing policy with strategy in waging war and how to define the desired outcome(s) of war. The book is a must read for students of strategic thought and policy analysts who seek to better understand the interconnected nature of war and strategy.

Strategy as a word is overused and misunderstood. Over the last few decades, the terms strategy and policy have become so comingled that the cognitive distinctions are muddled, further confusing efforts to sculpt viable strategy. Strategy and policy in the popular zeitgeist are synonyms, leading to confusion on their proper roles in national security decision making. In this context, Strachan contends that modern thinking lacks a strategic approach on war filtered through the prism of history. War strategy must be informed by history to wage more effective and efficient war. On the one hand, grand strategy, as articulated by national defense policies, aspires to meet requirements twenty to thirty years hence. Plans, on the other hand, need constant revision. In a world of instant gratification, this poses a conundrum for war strategists who must constantly deal with tactical policy questions, which shift with the political winds.

The 9/11 attacks were a defining moment in which global and personal experiences resulted in a strategic effect for all countries impacted. However, Strachan asserts that the end of the Cold War had a more profound impact on international relations and strategy than the 9/11 attacks. This is due to the fact that the Cold War was a focused effort with a unifying impetus (nuclear and conventional deterrence against Warsaw Pact aggression). Once the Berlin Wall fell and the Soviet empire imploded, that unifying glue dissolved. Visions of strategy morphed into articulations of policy.

Strachan uses the Global War On Terror (GWOT) as a prime example of this type of cognitive dissonance (strategy confused with policy). While hailed as a "strategy," GWOT is more a statement of policy than strategy per se. The post- 
9/11 stances of U.S. President George W. Bush and British Prime Minister Tony Blair, although touted as strategies, were in fact statements of policy. These policies in Iraq and Afghanistan were not linked to the regional realities of the Persian Gulf or Central Asia or the military capabilities of U.S. and British forces. Both leaders used GWOT parlance to treat the Iraq and Afghanistan situations as subordinate elements of a grand strategy vice those of localized policies. Strachan posits that the phrase GWOT intrinsically lacks a clear political focus due to the fact that terrorism is a means of waging war vice a strategy. Traditionally, war strategy has been shaped by space and time considerations, yet those same GWOT parameters were at best ambiguous. War needs a clearly defined enemy. Terrorists, while evoking are strong visceral response from a victimized populace, are more problematic in terms of identification due to a nebulous command and control structure.

Strachan further states that as terrorism is a means of waging war, GWOT is a strategically illiterate concept. As such, strategy and policy were further muddled as concepts, making a clear understanding of either more difficult. Labeling asymmetric warfare as "new" in the post-9/11 age also betrays how naïve western thought has become.

Strachan defines strategy as applying military means to a political end, which makes it inherently pragmatic. Strategy provides an interface between military capabilities and political objectives and is based upon recognition of the nature of war itself. Policy is a statement of intent. As the war interactively shapes the policy, the policy will change many times over the course of the war (the author cites WWII, Vietnam, the Cold War, and post-9/11 Iraq and Afghanistan as examples). Framed thusly, strategy shapes policy and must have an essential understanding of the nature of war. In the United States and Britain during the post-9/11 period, there is no governmental body responsible for creating strategy, which has been lost as an intellectual concept. It is rather policy on the fly to satisfy current exigent needs.

The author cites as a contrasting example Britain's grand strategy during WWII, which wove together a national policy dedicated to (first) surviving and (later) winning the war that encompassed coordination of resources and efforts with allies. In the modern age, in both the U.S. and Britain, strategy and policy are not the same but are treated as such due to the merging of the two during the waning years of the Cold War and continuing into the present. In the last few years, strategy was dislodged by buzzwords that were passing fads such as operational art, Revolution in Military Affairs, network centric warfare, and transformation, to name a few. Military thought further strayed from strategy into localized studies of anthropology, sociology, religion, geography, energy, resources, and food production-none of it bound together in an overarching strategy.

Strachan ends the book asserting that if wars are to be waged, waging them requires a firm grasp of strategy. In order to do so, strategy must be properly defined, framed, studied, and practiced to better serve a nation. Strachan's book is an essential for the military history student or strategist and has numerous examples that can be consulted time and again.

\section{Mark Roberts}

